\title{
JAN SZCZEPAN OTRĘBSKI - LITUANISTA DWÓCH UNIWERSYTETÓW W WILNIE I W POZNANIU
}

\author{
MAGDALENA GAWROŃSKA-GARSTKA
}

Przełom wieku XIX i XX oraz pierwszej połowy XX stulecia, to czasu przemian politycznych na niespotykaną dotąd skalę, restytucji państwa i kształtowania się współczesnej narodowej kultury. Czynniki powyższe a także tworząca się wówczas tożsamość narodowa społeczeństw żyjących w swoistej symbiozie, znacząco wpływały na dynamikę badań naukowych wschodnich rubieży Rzeczypospolitej. Istotną rolę w badaniach nad przeszłością tych ziem odgrywało językoznawstwo.

Wybitnym polskim językoznawcą, indoeuropeistą, slawistą i lituanistą był Jan Szczepan Otrębski, który stał się twórcą dwóch jakże ważnych dla nauki ośrodków lituanistycznych: najpierw w Wilnie na Uniwersytecie Stefana Batorego a następnie na Uniwersytecie w Poznaniu.

Urodził się 8 lutego 1889 roku w Pilicy koło Zawiercia. Po ukończeniu kieleckiego gimnazjum rozpoczął studia na Uniwersytecie Warszawskim, które uzupełniał w Lipsku. Był słuchaczem wykładów i zajęć prowadzonych przez znanych lingwistów: Karola Brugmanna, Ernsta Windischa, Augusta Leskiena, Eduarda Sieversa. Po wybuchu wojny w 1914 roku był internowany we wsi Colmen 40 km od Lipska. Po jej zakończeniu objął posadę nauczyciela w gimnazjum kaliskim.

Pracując jako nauczyciel, pod kierunkiem naukowym Jana Rozwadowskiego przygotował rozprawę doktorską Przyczynki do gramatyki porównawczej języków indoeuropejskich (Kraków 1919) na podstawie której uzyskał na krakowskim Uniwersytecie Jagiellońskim stopień doktora filozofii w zakresie językoznawstwa indoeuropejskiego i filologii słowiańskiej. W roku akademickim 1921/22 rozpoczął pracę na stanowisku zastępcy profesora Uniwersytetu Stefana Batorego w Wilnie 
(Gawrońska-Garstka i Walczak, 2014). Warto w tym miejscu podkreśli, iż odrodzona w 1919 roku wszechnica wileńska, nazwana imieniem swego szesnastowiecznego założyciela, króla Polski i wielkiego księcia litewskiego Stefana Batorego, była niewątpliwie źródłem postępu na ziemiach północno-wschodnich Drugiej Rzeczypospolitej, kształcąc specjalistów różnych zawodów, przyczyniających się do rozwoju kultury, oświaty, medycyny, administracji i gospodarki regionu (Gawrońska-Garstka, 2014).

Jan Otrębski wykładał na Wydziale Humanistycznym USB takie przedmioty jak: Wstęp do językoznawstwa, Język starocerkiewnosłowiański oraz Kurs praktyczny języka polskiego. Pełnił również funkcję kierownika Seminarium Indoeuropejskiego (od 1922 r.). W 1924 roku na Uniwersytecie Jagiellońskim w Krakowie na podstawie rozprawy zatytułowanej: $Z$ dziejów języka łacińskiego. O zachowaniu się wygłosowego -s po samogłosce dtugiej (1924) miała miejsce habilitacja Jana Otrębskiego.

We wrześniu 1930 roku został mianowany profesorem językoznawstwa indoeuropejskiego i filologii sanskryckiej w Uniwersytetu Stefana Batorego w Wilnie i rozpoczął wykłady między innymi z: Gramatyki sanskrytu, Gramatyki języka greckiego, a także prowadził ćwiczenia z Budowy wyrazów w językach bałtyckich.

Poza działalnością dydaktyczną na USB profesor Otrębski prowadził w tym okresie również intensywną pracę naukową. W jej wyniku powstały między innymi następujące prace: Przyczynki słowiańsko-litewskie, (1930); Wschodniolitewskie narzecze twereckie (1932, 1934).

Oprócz pracy naukowo-dydaktycznej profesor Otrębski sprawował także dodatkowe funkcje, aktywnie działając nie tylko w strukturach Uniwersytetu w Wilnie. Brał udział w pracach różnorodnych Komisji uczelnianych między innymi: Komisji do spraw Reaktywowania Katedry Filologii Litewskiej (w roku 1933/34), pełnił obowiązki prodziekana Wydziału Humanistycznego USB (w latach 1929/30 i 1930/31), a w roku akademickim 1931/32 do 1933/34 - obowiązki dziekana.

Profesor należał do różnych instytucji naukowych i organizacji pozauniwersyteckich. Był członkiem Towarzystwa Przyjaciół Nauk w Wilnie, członkiem Litewskiego Towarzystwa Naukowego oraz Instytutu Naukowo-Badawczego Europy Wschodniej. Warto podkreślić, iż kadra naukowo-dydaktyczna wszechnicy wileńskiej bardzo aktywnie uczestniczyła w różnorodnych inicjatywach oświatowych i kulturalnych na terenie Wilna i Wileńszczyzny. Jan Otrębski był prelegentem (a od stycznia 1931 roku także ich prezesem) na tak zwanych Powszechnych Wykładach Uniwersyteckich.

Po przekazaniu Wilna i przyległych doń terenów Litwie w 1939 roku odsunięto od władzy rektora USB i wyznaczono komisarza rządowego - profesora Uniwersytetu Kowieńskiego Ignasa Končiusa. 15 grudnia 1939 r. odbyły się na Uniwersytecie Stefana Batorego ostatnie wykłady, seminaria, egzaminy. Do Wilna przybyli uczeni litewscy zajmując miejsca w lokalach i bursach, zmuszając tym samym grono profe- 
sorskie i akademików do opuszczenia mieszkań. Profesorem USB, który podjął pracę na litewskim Uniwersytecie Wileńskim (wykładał wówczas Gramatykę historyczna języka litewskiego), był właśnie Jan Otrębski (za decyzję tę został uznany zdrajcą a jego postawę odebrano jako przykład narodowego zaprzaństwa (Walczak, 2010)). W latach 1940 - 1944 pełnił funkcję kierownika Katedry Języka Polskiego i Filologii Klasycznej, był członkiem Instytutu Języka Litewskiego, uczestniczył w opracowaniu Stownika języka litewskiego (Lietuviu kalbos žodynas), publikował swe artykuły w „Gazecie Codziennej” a także wygłosił przez radio (w języku polskim) kilka odczytów z zakresu lituanistyki.

Po drugiej wojnie światowej profesor Otrębski przeniósł się na Uniwersytet w Poznaniu. Upowszechniając naukę wśród studentów, kontynuował dzieło rozpoczęte na USB w Wilnie. Prowadził wykłady między innymi: z fleksji języka litewskiego, gramatyki sanskrytu, gramatyki porównawczej języków bałtyckich, oraz ćwiczenia w czytaniu tekstów sanskryckich, litewskich, łotewskich i inne (Gawrońska-Garstka, 2005).

Działalność profesora Otrębskiego na poznańskiej uczelni związana była głównie z Katedrą Filologii Bałtyckiej, której zasadność utworzenia postulował już we wrześniu 1945 roku. Od samego początku od 1947 roku do 1960 był jej kierownikiem. W ramach Katedry pracowano nad zagadnieniami językoznawstwa bałtyckiego na tle porównawczym języków indoeuropejskich, prowadzono badania lituanistyczne obejmujące $\mathrm{w}$ szczególności studia nad językiem litewskim i jego dialektami, a także zajmowano się zagadnieniami słowotwórstwa i semantyki oraz morfologii języków bałtyckich. Współpracując z Zakładem Fonograficznym Uniwersytetu Poznańskiego, nagrano teksty litewskie z uwzględnieniem intonacji, iloczasu i przycisku, zebrane w pracy pt. Przeglad podstawowych cech języka litewskiego (1954).

Po przejściu na emeryturę z dniem 30 września 1960 roku Katedrę Filologii Bałtyckiej przejął doc. Czesław Kudzinowski.

$\mathrm{Na}$ emeryturze profesor niestrudzenie pracował naukowo, a jako ceniony bałto$\log$ był zapraszany na wykłady do wielu uniwersytetów za granicą (Praga, Berlin, Hamburg, Neapol) gościł też na konferencjach krajowych i zagranicznych.

W językoznawstwie kontynuował kierunek szkoły młodogramatycznej. Jako członek wielu stowarzyszeń naukowych w kraju i za granicą, człowiek o wielkim zasobie wiedzy, talencie pedagogicznym, niezwykle pracowity i sumienny w swej działalności naukowej podkreślał wielokrotnie ważność metody porównawczej w badaniach językowych.

Przegląd prac Jana Otrębskiego dotyczących lituanistyki: gwar Wileńszczyzny i języków bałtyckich ukazuje przede wszystkim wielostronność i zróżnicowanie tematyczne prowadzonych przez profesora badań: onomastycznych, etymologicznych i dialektologicznych. Zarówno w opisie dialektów litewskich (badanie gwar twereckich), jak i w poszukiwaniach etymologicznych i onomastycznych opierał się 
Otrębski na samodzielnie zebranym materiale i źródłach. Prace w terenie wsparte wiedzą teoretyczną zdobytą podczas studiów w Lipsku uzupełnił o obserwacje żywego języka. Oprócz słownikowych śladów wzajemnych kontaktów języków bałtyckich i języka polskiego szukał Otrębski także cech fonetycznych polszczyzny, które jego zdaniem nawiązywały do zjawisk bałtyckich, a zwłaszcza języka Jadźwingów. Efektem tych badań była praca pt. Udział Jadźwingów w ukształtowaniu jezzyka polskiego.

Pasją życiową profesora były przede wszystkim badania bałtologiczne reprezentowane $w$ pracach $z$ dialektologii, onomastyki, słowotwórstwa. O fascynacji językiem litewskim świadczy także współpraca Otrębskiego z Michałem Brensztejnem (dyrektorem Biblioteki Uniwersytetu Wileńskiego) przy opracowaniu i wydaniu w Wilnie w 1927 r. książki pt.: Dajny litewskie zapisane przez Adama Mickiewicza.

Znaczącym wydarzeniem wydawniczym stała się publikacja głównego lituanistycznego dzieła Otrębskiego - Gramatyki języka litewskiego składającego się z trzech tomów: I: Wiadomości wstępne. Nauka o głoskach, (1958); II: Nauka o budowie wyrazów, (1965); III: Nauka o formach, (1956).

W zamierzeniach Profesora książka miała być gramatyką opisową współczesnego języka literackiego, lecz w rzeczywistości, w toku pracy, zakres badań rozszerzono także o dawne dialekty i zabytki językowe.

Gramatyka... była ukoronowaniem pracy Otrębskiego nad językiem litewskim i spotkała się z wielkim uznaniem uczonych w kraju i na świecie. Za pracę naukową, a zwłaszcza za Gramatykę języka litewskiego otrzymał Otrębski w 1958 roku Krzyż Komandorski Odrodzenia Polski.

W kręgu zainteresowań uczonego były także stosunki językowe bałto-słowiańskie i ich rola w ukształtowaniu języka polskiego. W polskim języku regionalnym na Wileńszczyźnie używano także niektórych słów litewskich. To też interesowało Otrębskiego, który zebrał materiał językowy wzajemnych śladów oddziaływania języków litewskiego oraz polskiego i przedstawił w pracy opublikowanej w 1931 roku pt. Lituanizmy stownikowe $w$ dialekcie polskim na Wileńszczyźnie, i uzupełnił artykułem z 1965 roku Uwagi o polszczyźnie litewskiej.

Profesor Otrębski prowadził badania etymologiczne i onomastyczne zwłaszcza dotyczące litewskich nazw miejscowych i nazw wodnych. Badania te rozpoczął jednak dopiero wtedy, gdy ukazał się Lietuviu kalbos rašybos žodynas, (1948) zawierający spis nazw miejscowości i wód. Wart uwagi jest też napisany z okazji V Międzynarodowego Kongresu Slawistów w Sofii w 1963 roku, artykuł Slawizacja litewskich nazw wodnych i miejscowych, w którym omówił podobieństwa i zgodność nazw litewskich z ich słowiańskimi odpowiednikami.

Profesor Otrębski zmarł po długiej i ciężkiej chorobie 25 kwietnia 1971 roku w Poznaniu i został pochowany na cmentarzu w Puszczykowie. Wielopłaszczyznowość i ważne wyniki badań lituanistycznych Otrębskiego stanowią trwały dorobek nauki w tej dziedzinie, a jego fundamentalne dzieło Gramatyka języka litewskiego 
jest syntezą poglądów uczonego na ogół zjawisk charakterystycznych dla historii tego języka. I choć dziś badania lituanistyczne istotnie się rozwinęły to jednak prace Jana Otrębskiego zachowują nadal swą wartość.

\section{Bibliografia}

Gawrońska-Garstka, M. 2014. Jan Szczepan Otrębski-życie i dzieło (1889-1971). Poznań: Wydawnictwo Rys. 425 str.

Gawrońska-Garstka, M. 2015. „Oddziaływanie Uniwersytetu Stefana Batorego na Wilno i Wileńszczyznę w dwudziestoleciu międzywojennym”. W zbiorze: Skorupska-Raczyńska, E. i J. Rutkowska (red.). Dziedzictwo kulturowe regionu pogranicza. Gorzów Wielkopolski: Wydawnictwo PWSZ. 199-209.

Gawrońska-Garstka, M. 2016. Uniwersytet Stefana Batorego w Wilnie. Uczelnia ziem pótnocnowschodnich Drugiej Rzeczypospolitej (1919-1939). Poznań: Wydawnictwo Rys. 371 str.

Gawrońska-Garstka, M. i B. Walczak. 2014. Jan Szczepan Otrębski. Rozprawy i studia slawistyczne i polonistyczne. Poznań: Wydawnictwo PTPN. 154 str.

Walczak, B. 2010. „Meandry tożsamości narodowej”. W zbiorze: Cyran, G. i E. Skorupska-Raczyńska (red.). Meandry tożsamości. Język. Religia. Tożsamość. Gorzów Wielkopolski/Szczecin: PWSZ. 9-18. 